\title{
SIKAP DAN ETIKA DALAM MENGHADAPI IKHTILAF PENDAPAT MAZHAB FIQIH
}

\author{
Muhammad Zuhdi \\ zukhdi@gmail.com \\ Dosen STIS Ummul Ayman Meureudu Pidie
}

Faisal

Dosen Fakultas Syariah IAIN Langsa

fais_alfaerah@yahoo.com

\begin{abstract}
Dissent is a common thing, it even becomes sunnatullah or human nature. In the development of Islamic law, Ikhtilaf (differences of opinion) regarding the establishment of law has occurred among the Companions of the Prophet. When the Apostle was still alive, but differences of opinion could soon be reconciled by returning to the Messenger of Allah. Among friends after the Prophet's death often arise differences of opinion in establishing the law on certain matters. Dissent in the tradition of Islamic scholars is not new. Countless works have been written by special Islamic scholars to study, compare, and then discuss different views with their respective arguments. The attitude of the Companions of the Prophet when facing differences among them, the attitude of the Imams mazhab of the Muslim, the wise and wise attitude in addressing the disputes between them.
\end{abstract}

Keywords: Ikhtilaf, Mazhab, Attitude

\begin{abstract}
Abstrak. Perbedaan pendapat adalah suatu yang biasa terjadi, bahkan menjadi sunnatullah atau fitrah manusia. Dalam perkembangan hukum Islam, Ikhtilaf (perbedaan pendapat) mengenai penetapan hukum telah terjadi di kalangan para sahabat Nabi saw. Ketika Rasul masih hidup, tetapi perbedaan pendapat segera dapat dipertemukan dengan mengembalikan kepada Rasulullah saw. Kalangan sahabat setelah Rasul wafat sering timbul perbedaan pendapat dalam menetapkan hukum terhadap masalah tertentu. Perbedaan pendapat dalam tradisi ulama Islam, bukan hal yang baru. Tidak terhitung jumlahnya karya telah ditulis oleh ulama Islam khusus untuk mengkaji, membandingkan, kemudian mendiskusikan berbagai pandangan yang berbeda-beda dengan argumentasi masing-masing. Sikap para sahabat Nabi ketika menghadapi perbedaan di kalangan mereka, sikap para Imam-Imam mazhab kaum muslimin, sikap bijak dan arif dalam menyikapi perselisihan di antara mereka.
\end{abstract}

Kata Kunci: Ikhtilaf, Mazhab, sikap

\section{Pendahuluan}

Ihktilaf (Perbedaan pendapat) mengenai masalah-masalah yang ada dalam fikih harus disikapi dengan arif dan bijaksana, tidak boleh besikap apriori dengan langsung menyalahkan satu pendapat dan membenarkan pendapat lainnya. Sikap apriori yang semacam ini dapat memicu terjadinya perpecahan di kalangan umat. Selain itu harus juga meninggalkan fanatisme individu, mazhab dan golongan yang merupakan suatu hal yang patut dipertimbangkan dalam menciptakan 
kerukunan dalam masyarakat serta dengan senantiasa berprasangka baik dan tidak saling mencela. Untuk menyikapi perbedaan pendapat diperlukan meneladani sikap Nabi Muhammad saw dalam menghadapi perbedaan pendapat di kalangan sahabatnya. Sikap para sahabat Nabi ketika menghadapi perbedaan di kalangan mereka, sikap para Imam-Imam mazhab kaum muslimin, sikap bijak dan arif dalam menyikapi perselisihan di antara mereka. Perbedaan pendapat adalah suatu yang biasa terjadi, bahkan menjadi sunnatullah atau fitrah manusia sebagaimana Allah berfirman:
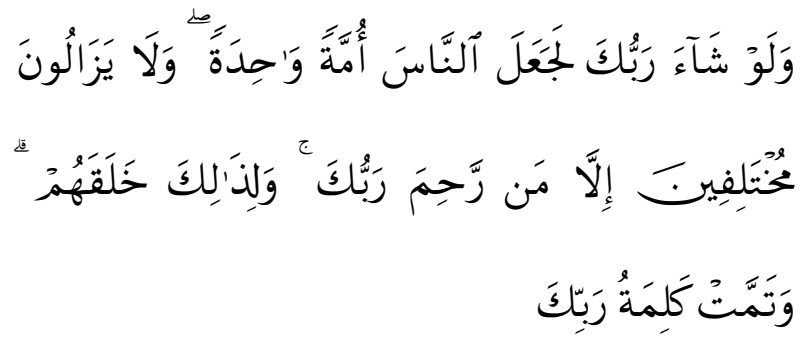

"Dan seandainya Tuhanmu kehendaki, niscaya Dia jadikan manusia itu umat yang satu, tetapi mereka senantiasa berselisih, kecuali yang dirahmati Tuhanmu, dan untuk itulah Dia menciptakan mereka" (QS. Hud: 118-119)

Menurut Ibnu Katsir ayat tersebut menerangkan bahwa, "Allah mengkabarkan bahw Allah swt mampu menjadikan manusia seluruhnya satu umat, baik dalam keimanan atau kekufuran, sebagaimana firmanNya yang lain "Seandainya Tuhanmu kehendaki, niscaya berimanlah semua manusia di bumi", kemudian firmanNya "tetapi mereka senantiasa berselisih, kecuali yang dirahmati Tuhanmu" artinya perbedaan akan senantiasa terjadi antara manusia, baik tentang agama, keyakinan, millah (ajaran), mazhab, dan pendapat-pendapat mereka. Firman selanjutnya "kecuali yang dirahmati Tuhanmu” artinya kecuali orang-orang yang dirahmati yang mengikuti Rasul-Rasul dan berpegang teguh kepada perintah-perintah agama, dan seperti itulah kebiasaan mereka hingga masa penutup para Nabi dan Rasul, mereka mengikutinya, membenarkannya, dan menjadi pembelanya. Beruntunglah dengan kebahagiaan dunia dan akhirat karena mereka adalah Firqah an-Najiyah (kelompok yang selamat) sebagaimana yang diisyaratkan dalam sebuah hadis musnad dan sunan dari banyak jalur yang saling menguatkan satu sama lain, "Sesungguhnya Yahudi berpecah menjadi 71 golongan, dan Nasrani menjadi 72 golongan, dan umat ini akan berpecah menjadi 73 golongan, semua masuk neraka kecuali satu golongan”, mereka bertanya "Siapa mereka ya Rasulullah?” Rasulullah saw menjawab, "Apa-apa yang ada aku dan sahabatku di atasnya". Diriwayatkan oleh alHakim dalam Mustadraknya dengan tambahan ini."

Hadis tersebut memberikan isyarah bahwa, khilafiyah tidak dapat dihilangkan kecuali kembali kepada pokok agama yaitu alQuran dan hadis serta perkataan atau perbuatan sahabat.

\section{Pengertian Ikhtilaf}

Secara bahasa ikhtilaf berasal dari kata khalafa, yakhlifu, khalfan. Adapun makna khilafan yaitu berbeda, mengganti, membelakangi, meninggalkan keturunan. ${ }^{2}$ Khilafan dapat juga diartikan dengan bertentangan, tidak sepakat, berselisih paham, perbedaan pendapat atau pikiran yang masih

${ }^{1}$ Imam Ibnu Katsir, Tafsir Al-Qur'an $A l$ 'Azhim, Juz 4, Cet. 2, (Cairo: Dar Al-Tayyibah lin Nasyr wat Tauzi', 1999M/1240H), h. 361-362.

${ }^{2}$ Ahmad Muhammad „Ali al Faiyumi al-Muqri, Misbahul al-Munir, (Bayrut: Maktabah al- „Asriyah 1997) h. 95 
terjadi di kalangan ulama. $^{3}$ Perbedaan pendapat secara linguistik dalam kajian bahasa inggris, dapat diterjemahkan dalam beraneka ragam yaitu, diffence of opinion, distingtion, atau controversi. Sedangkan secara istilah ikhtilaf didefinisikan dengan beragam definisi di antaranya adalah:

Taha Jabir mengatakan bahwa ikhtilaf adalah: ${ }^{4}$

"Ikhtilaf dan Mukhalifah proses yang dilalui melalui metode yang berbeda, antara seorang dan yang lainnya dalam bentuk perbuatan atau perkataan."'

Dan menurut al Jurjani ikhtilaf yaitu, ${ }^{5}$

"Perbedaan pendapat yang terjadi di antara beberapa pertentangan untuk menggali kebenarannya dan sekaligus untuk menghilangkan kesalahannya."

Dari dua definisi yang dijelaskan oleh beberapa pakar hukum Islam dapat dipahami bahwa, perbedaan pendapat adalah perbedaan cara atau metode yang ditempuh oleh seseorang yang berbeda dengan orang lain, baik perkataan, perbuatan, prinsip, keadaan. Namun al-Jurjani menjelaskan bahwa, tujuan atau maksud dari perbedaan pendapat untuk memastikan kebenaran atau menolak kebatilan. Hal ini berbeda dengan definisi lain yang tidak menjelaskan tujuan dari ikhtilaf. Oleh karena itu diperlukan suatu metode yang benar untuk mencari kebenaran dan kesalahan dalam ikhtilaf sebagai antisipasinya, munculah ilmu khilaf. Taha Jabir menjelaskan bahwa, ilmu khilaf adalah ilmu yang membahas kemungkinan terpeliharanya persoalan yang diperdebatkan yang dilakukan

${ }^{3}$ Luis Ma ${ }^{\mathrm{ee}} l u f$, al-Munjid, hlm. 193. Depdikbud, Kamus Besar Bahasa Indonesia, Cet. Ketiga, (Jakarta: PN Balai Pustaka, 2005), hlm. 420

${ }^{4}$ Taha Jabir Fayyadl Al-Ulwani, Adabul Ikhtilaf fi al-Islam, terj. Abu Fahmi, (Jakarta: 1991), h. 22

5 „Ali Muhammad Al-Jurjani, At-Ta“rifat, (Dar al Aqsa ${ }^{\text {ee }}$ t.t), h. 99 oleh para Imam mazhab dan sekaligus ilmu yang membahas perselisihan tanpa sandaran yang yang jelas kepada dalil yang dimaksud. ${ }^{6}$

Ilmu ikhtilaf menekankan cara menetapkan hukum yang sesuai dengan apa yang dilakukan oleh para Imam mazhab sebelumnya dan juga untuk menolak perselisihan yang tidak diharapkan. Uraian di atas memperlihatkan bahwa, ikhtilaf yang asalnya hanya sebatas diskusi atau bantahan tiap-tiap mazhab atau pengikutnya, telah melahirkan ilmu yang mandiri, yakni ilmu khilaf. $^{7}$

Dari beberapa penjelasan pengertian di atas, maka yang dimaksud ikhtilaf dalam pembahasan ini adalah perbedaan pendapat di antara ahli hukum Islam dalam menetapkan sebagian hukum Islam yang bersifat furu', bukan pada masalah hukum Islam yang bersifat ushul, yang disebabkan perbedaan pemahaman atau perbedaan metode dalam menetapkan hukum suatu masalah.

\section{Sebab-sebab Terjadinya Ihktilaf}

Dalam perkembangan hukum Islam, Ikhtilaf (perbedaan pendapat) mengenai penetapan hukum telah terjadi di kalangan para sahabat Nabi saw. Ketika Rasul masih hidup, tetapi perbedaan pendapat segera dapat dipertemukan dengan mengembalikan kepada Rasulullah saw. Kalangan sahabat setelah Rasul wafat sering timbul perbedaan pendapat dalam menetapkan hukum terhadap masalah tertentu.

Perbedaan pendapat dalam tradisi ulama Islam, bukan hal yang baru. Tidak terhitung jumlahnya karya telah ditulis oleh ulama

\footnotetext{
${ }^{6}$ Taha Jabir Fayyadl Al-Ulwani, Adabul Ikhtilaf...., h. 22.

${ }^{7}$ Dedi Supriadi, Perbandingan Madzab dengan Pendekatan Baru, (Bandung: Pustaka Setia, 2008), h. 69-71
} 
Islam khusus untuk mengkaji, membandingkan, kemudian mendiskusikan berbagai pandangan yang berbeda-beda dengan argumentasi masing-masing. Kitab yang berisi perbedaan pendapat dalam bidang hukum Islam, misalnya yaitu kitab al-Mughni karya Imam Ibnu Qudamah dicetak 15 jilid. Kitab ini dapat dianggap sebagai ensiklopedi berbagai pandangan dalam bidang hukum Islam dalam berbagai mazhabnya. Karena Ibnu Qudamah tidak membatasi diri pada empat mazhab yang populer saja. Tetapi Ibu Qudamah juga merekam pendapat-pendapat ulama lain yang hidup sejak masa sahabat, tabi'in dan tabi' tabi'in. Contoh ini berlaku pada semua disiplin ilmu Islam yang ada. Tidak terbatas pada ilmu hukum saja, tetapi juga pada tafsir, ulumul Qur'an, syarah hadis, ulumul hadis, tauhid, usul fikih, qawa'id fiqhyah, maqashidus syariah, dan lain-lain.16 Kitab lain yaitu seperti kitab al-Mabsut karya Imam Sarkhasi, Sarkhasi menjelaskan hukum dengan membuat perbandingan dengan mazhab-mazhab lain, walaupun Sarkhasi bermazhab Hanafi. Demikian juga Ibnu Rusdi telah mengarang kitab Bidayatul Mujtahid. Kitab tersebut menjelaskan hukum dalam berbagai mazhab dan sejumlah kitab lainnya yang menyebutkan perbedaan pendapat. ${ }^{8}$

Terjadi perbedaan pendapat dalam menetapkan hukum Islam, di samping disebabkan oleh faktor manusiawi, juga faktor agama. Faktor tersebut mengalami perkembangan sepanjang pertumbuhan hukum pada generasi berikutnya, sehingga kadang-kadang menimbulkan pertentangan keras, terutama di kalangan masyarakat awam. Tetapi pada masa kemajuan ilmu pengetahuan dan teknologi sekarang ini, masalah khilafiah dalam persolaan furu'iyah tidak begitu dipersoalkan. Hal ini disebabkan

${ }^{8}$ Ibid., h. 57. adanya usaha-usaha untuk memberikan pengertian dan pemahaman terhadap ikhtilaf dan cara menyikapinya.

Para pakar hukum Islam berbeda-beda dalam mengelompokkan jumlah faktor penyebab ikhtilaf. Adapun sebab-sebab terjadi perbedaan pendapat secara umum, yaitu sebagai berikut:

1. Muhammad Abdul Fath al-Bayanuni dalam bukunya: Dirasat fi Al-ikhtilaf AlFiqhiyyah menjelaskan bahwa, asal perbedaan hukum-hukum fikih disebabkan timbulnya ijtihad terhadap hukum, terutama pasca-Nabi dan sahabat meninggal dunia". al-Bayanuni menjelaskan, 4 faktor utama perbedaan, yaitu perbedaan pendapat ada atau tidak ada nas Al-Qur'an atau hadis yang digunakan, perbedaan dalam memahami suatu nas, perbedaan dalam metode jama' dan tarjih, perbedaan dalam kaidah ushul fiqih dan sumber-sumber hukum. ${ }^{9}$

2. Taha Jabir dalam bukunya Adabul Ikhtilaf menjelaskan, faktor-faktor penyebab ikhtilaf ada empat macam, yaitu faktor bahasa, faktor periwayatan sunnah, faktor kaidah dan metode istinbath. ${ }^{10}$

3. Mahmud Syaltut mengungkapkan bahwa, ikhtilaf di kalangan para ulama terjadi disebabkan oleh beberapa sebab yang sulit dihindari, yaitu:

a. al-Quran terdapat lafad-lafad yang memiliki arti ganda (musytarak), seperti kata quru'. Kata quru' memiliki arti suci dan haidh. Imam Abu Hanifah berpendapat, perempuan yang ditalak oleh suaminya harus beriddah tiga kali

\footnotetext{
${ }^{9}$ Muhammad Abu al-Fath al-Bayanuni, Dirasat fi Ikhtilafat al-Fiqhyah, terj. „Ali Mustafa Ya"kub ( Jakarta: Pustaka Firdaus 1997) h. 20-21

${ }^{10}$ Taha Jabir Fayyadl Al-Ulwani, Adabul Khilaf..., h. 98-105
} 
haidh. Sementara Imam Syafi'i berpendapat, perempuan yang dicerai oleh suaminya harus beriddah tiga kali suci. al-Quran juga terdapat kata Hakiki dan Majazi, para ulama sering terjadi perbedaan perdapat dalam menetapkan hukum ketika menghadapi kata hakikat dan majaz.

b. Perbedaan waktu, tempat dan kasus yang dihadapi. Tidak semua kasus yang dihadapi oleh para ulama, didapati nas hukumnya. Sehingga mereka harus berijtihad. Ketika berijtihad para ulama menggunakan metodologi yang belum tentu sama antara yang satu dengan yang lain, sehingga menimbulkan hukum yang berbeda-beda.

c. Riwayat. Para ulama tidak sama tingkatan dalam menerima hadis Rasullah saw. Persoalan tersebut disebabkan berbeda jumlah sahabat yang dapat dijumpai. Sementara para sahabat juga tidak sama tingkatan dalam mendengar hadis dari Nabi. Ada shahabat yang hanya mendengar satu hadis saja dan ada sampai puluhan, ratusan dan bahkan ribuan hadis. Sehingga ada hadis yang sampai kepada sebahagian ulama dan tidak sampai kepada sebahagian yang lain.

d. Berbeda dalam menggunakan kaidahkaidah ushul dalam menetapkan hukum.

e. Berbeda dalil yang digunakannya, seperti istihsan, maslahah mursalah, qaul sahabat, 'uruf, dan lain-lain.

f. Perbedaan kapasitas intelektual masingmasing ulama. ${ }^{11}$

Dari uraian di atas dapat dipahami bahwa, masalah khilafiah adalah masalah yang selalu

\footnotetext{
${ }^{11}$ Mahmud Syaltut dan M. Ali al-Sayis, Perbandingan Mazhab, (Bulan Bintang, Jakarta, 1996), h. $16-17$
}

aktual dalam realitas kehidupan manusia, karena ada daya berpikir yang dimiliki yang mengakibatkan orang berpikir dinamis dalam menetapkan suatu hukum. Dan dapat disimpulkan dan dikelompokkan ke dalam empat sebab utama: 1. Perbedaan pendapat tentang valid-tidaknya suatu teks dalil syar'i sebagai hujjah. 2. Perbedaan pendapat dalam menginterpretasikan teks dalil syar'i tertentu. 3. Perbedaan pendapat tentang beberapa kaidah ushul fikih dan beberapa dalil hukum syar' $i$ (dalam masalah-masalah yang tidak ada nas-nya), seperti qiyas, istihsan, mashalih mursalah, 'urf, saddud-dhara'i, syar'u man qablana, dan lain-lain. 4. Perbedaan pendapat yang dilatar belakangi oleh perubahan situasi, kondisi, tempat, masyarakat, dan semacamnya. Dan masih banyak lagi pendapat-pendapat para pakar terhadap sebabsebab terjadinya perbedaan pendapat tersebut.

\section{Sikap Dan Etika Dalam Menghadapi Perbedaan Pendapat}

Berkenaan dengan sikap dan etika dalam menghadapi perbedaan pendapat dengan cara menyikapi perbedaan pendapat dan pandangan yang dicontohkan Rasulullah saw., yaitu dengan cara terlebih dahulu mendengar seluruh pendapat yang berbeda-beda dari para sahabatnya yang mulia.

Banyak sekali peristiwa dan kasus yang membuktikan sikap Rasulullah ini. Prinsip mendengar dan bermusyawarah yang diterapkan oleh Rasulullah tersebut tidak lain merupakan perwujudan dari firman Allah Swt dalam surat Ali Imran ayat 159 yang berbunyi sebagai berikut:

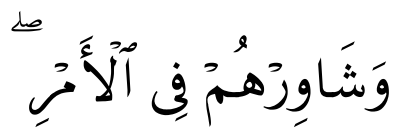

dan bermusyawaratlah dengan mereka dalam urusan itu... (QS. Ali Imran: 159) 
Begitu juga dalam surat al Syuraa ayat 38 Allah berfirman:

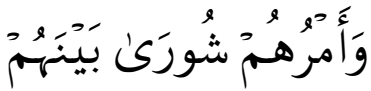

“......sedang urusan mereka (diputuskan) dengan musyawarat antara mereka....(QS. al Syuura: 38 )

“......sedang urusan mereka (diputuskan) dengan musyawarat antara mereka....(QS. al Syuura: 38)

Rasulullah saw dalam sejarah selalu berusaha mendengar pendapat dari para sahabatnya, kemudian menyaring sekaligus memilih pendapat terbaik dan bermanfaat. Contahnya al-Hubab bin al-Munzir bin al-Jumuh menyarankan, agar rumah yang ditempati Rasulullah saw dalam perang Badar diubah posisinya dan dimajukan hingga mendekat ke beberapa sumber air yang telah dikuasai oleh umat Islam dalam wilayah, di mana terdapat banyak sumber air tersebut merupakan salah satu posisi paling strategis untuk pertahanan dan penyusunan kekuatan umat Islam. Rasulullah saw dan para sahabatnya kemudian melakukan perubahan sesuai saran al-Hubab tersebut. Saran tersebut membuahkan manfaat yang besar bagi kaum Muslimin saat itu.

Dari keterangan ayat dan hadis menunjukkan, perbedaan pada masa Nabi diselesaikan dengan musyarawah. Teladan yang diperlihatkan Nabi saw dari hadis yang riwayat Imam Bukhari dan Imam Muslim meriwayatkan dari Abdullah bin Umar, yang artinya yaitu: $^{12}$

Artinya:dari Ibnu Umar berkata: Nabi saw mengatakan bagi kami ketika kembali dari Azhab ( Janganlah ada satupun yang shalat Ashar kecuali di perkampungan Bani Quraizhah. Lalu ada di antara mereka mendapati waktu Ashar di tengah jalan, maka

\footnotetext{
${ }^{12}$ Imam Bukhari, Sahih al-Bukhari, Jilid 1,
} (Bairut: Dar al Kutub al 'ilmiah, tth), h. 321 berkatalah sebagian mereka: "Kita tidak shalat sampai tiba di sana." Yang lain mengatakan: "Bahkan kita shalat saat ini juga. Bukan itu yang beliau inginkan dari kita." Kemudian hal itu disampaikan kepada Rasulullah saw, namun Rasul tidak mencela salah satunya." (H.R. Bukhari)

Berdasarkan Hadis di atas dapat disimpulkan bahwa, Nabi tidak mencela salah satu pihak yang berlawanan pendapat dengan kata-kata bid'ah, sesat, kafir, dan sebagainya, bahkan tidak mencela salah satunya. Masingmasing pihak punya argumen. Sahabat yang shalat Ashar di tengah jalan bukan ingkar kepada Nabi, namun mereka mencoba shalat di awal waktu sebagaimana diperintahkan Allah swt dan Rasul-Nya. Adapun sahabat yang shalat belakangan di perkampungan Bani Quraizah juga tidak melanggar perintah shalat di awal waktu, namun mereka mengikuti perintah Nabi di atas. Imam mazhab saling memuji satu sama lain, walaupun mereka berbeda pendapat. Mereka saling menghargai, dan menghormati perbedaan pendapat. Pernyataan tersebut dapat dilihat beberapa contoh dan ungkapkan di bawah ini,

1. Imam Abu Hanifah. Para sahabat Imam Hanafi dan Imam Syafi'i , serta Imam-Imam yang lain, berpendapat bahwa, wajib membaca basmalah dalam shalat. Karena basmalah merupakan salah satu dari ayat dalam surah Al-Fatihah. Pada kebiasaannya di Kota Madinah dilaksanakan shalat berjama'ah dengan Imam-Imam bermazhab Maliki. Para pengikut Hanafi dan Syafi'i ketika shalat mengikuti Imam bermazhab Maliki mereka tidak mempersoalkannya. ${ }^{13}$

2. Imam Syafi'i pernah shalat subuh di

${ }^{13}$ Ahmad bin Abdul al-Rahim Al-Faruqi alDahlawi, Al-Inshaf fi Bayani Asbabil ikhtilaf fi Ahkam al-Fiqhiyah (.tp, t.t.), hlm. 42 
dekat kuburan Abu Hanifah tanpa kunut untuk menghormati Imam Abu Hanifah, pada hal kunut menurut Imam Syafi'i termasuk perbuatan sunat $a b^{\prime} a d .{ }^{14}$ Ini menunjuk betapa mulia dan hormat Imam Syafi'i kepada ulama, sekalipun tidak sesuai dengan mazhabnya.

3. Imam Nawawi salah seorang mujtahid tarjih dalam mazhab Syafi'i berkata: "Dan adapun yang terkait masalah ijtihad, tidak mungkin orang awam menceburkan diri ke dalamnya, mereka tidak boleh mengingkarinya, tetapi itu tugas ulama. Kemudian para ulama hanya mengingkari dalam perkara yang disepakati para imam. Adapun dalam perkara yang masih diperselisihkan, maka tidak boleh ada pengingkaran di sana. Karena berdasarkan dua sudut pandang setiap mujtahid adalah benar. Ini adalah sikap yang dipilih oleh mayoritas para ulama peneliti (muhaqqiq). Sedangkan pandangan lain mengatakan bahwa, yang benar hanya satu, dan yang salah kita tidak tahu secara pasti, dan dia telah terangkat dosanya." 15 Penyataan Imam Nawawi menjelaskan bahwa, yang boleh diingkari hanyalah yang jelas-jelas bertentangan dengan nas qath'i (teks yang pasti) dan ijma'. Adapun masalah ijtihadiyah, maka tidak bisa saling menganulir/ membatalkan.

4. Ibnu Taymiyah berkata: "Seandainya setiap kali dua orang muslim yang berbeda pendapat dalam suatu masalah saling menjauhi dan memusuhi, niscaya tidak akan tersisa sedikitpun ikatan ukhuwah di antara kaum muslimin".

\footnotetext{
${ }^{14}$ Ibid.

15 Muhyiddin Yahya bin Syaraf al-Nawawi, Syarh Sahih Muslim, Juz. 1, hlm. 131
}

Pernyataan ibnu Taimiyah ini menegaskan perbedaan pendapat bukan menimbulkan terjadinya permusuhan sesama muslim dan bukan cara memutuskan tali persuadaraan. ${ }^{16}$

Para Imam mazhab tidak hanya menghormati pendapat mazhab lain, bahkan di antara mereka saling memuji, di antaranya Imam Syafi'i memuji Imam Abu Hanifah, yaitu:

Imam Syafi'i : Siapa saja mau tahu ilmu fikih, maka bergantung kepada Abu Hanifah, siapa yang mau tahu sejarah, maka bergantung pada Muhammad ibn Ishaq. Dan siapa saja yang mau tahu hadis, maka, bergantung pada Imam Malik dan siapa saja mau tahu tafsir, maka bergantung pada maqatil bin Sulaiman."17

Imam Syafi'i juga memuji Imam Malik, pernyataan ini dapat dilihat di bawah ini;

Imam Syafi'i mengatakan: Apabila datang hadis dari Imam Malik, maka itu bagaikan bintang, siapa yang menginginkan, maka, dia termasuk dalam keluarga Malik. ${ }^{18}$

Demikian juga Imam Ahmad bin Hanbal memuji Imam as-Syafi'i . Pada sebuah riwayat disebutkan, yaitu;

Muhammad bin Harun al-Zanjani berkata, Abdullah bin Ahmad berkata: Saya berkata kepada bapakku (Ahmad bin Hanbal), siapakah Syafi'i itu, sehingga engkau banyak mendo'akannya. Ahmad bin Hanbal berkata, wahai anakku! Dia itu seperti matahari bagi dunia, kesehatan bagi manusia. Apakah yang

${ }^{16}$ Taqiyuddin Ahmad bin Abdus Salam bin Abdullah bin Taimiyah al Harrani, Majmu ah alFatawa, Juz ke 20 (Bairut: Dar al-Arabiyah, 1398 H), hlm. 364-366

17 Abu Abdillah Syamsuddin Muhammad bin Ahmad bin Utsman ad Dhahabi, Siyaru A 'lami anNubala, Juz 10, hlm. 45

${ }^{18}$ Ibn Kashir, Al- Bidayah wal al-Nihayah, Jil.5, (Cairo Dār: al-Fajar, 1998), hlm.188. 
bisa menggantikan kedua hal itu. ${ }^{19}$

Dari berbagai keterangan dan sejarah perkembangan hukum Islam menunjukkan bahwa, perbedaan pendapat semenjak masa Nabi Muhamamad, masa sahabat, tabi'in sampai ke masa Imam mazhab terus berlangsung, tetap dalam suasana yang harmonis, saling menghargai, saling memuji dan toleransi. Sementara Imam bin Abdil Barr dalam kitabnya; Jami' Bayanil Ilmi Wa Ahlihi menyebutkan beberapa ungkapan ulama yang masyhur di antaranya dari Imam Qatadah ra yang berbunyi:

$$
\text { من لم يعرف الاختلاف لم يشم الفقه بأنفهه }
$$

"Barang siapa yang tidak mengenal adanya perbedaan pendapat, maka dia belum mencium fikih dengan hidungnya. "20

Demikian juga al-Amidi menyebutkan perkataan Imam Sa'id bin Arubah dalam alMuwafaqah, dengan bunyinya yaitu:

Dari Sa'id bin Ibn Abi Arubah berkata: "Barang siapa yang belum pernah mendengar adanya perbedaan pendapat, maka janganlah kalian anggap dia sebagai seorang yang alim". 21

Imam Utsman bin Atha' meriwayatkan dari ayahnya berkata yang artinya: diriwayatkan dari Usman bin Atha' dari ayahnya berkata: Tidak sepantasnya bagi seseorang untuk memberikan fatwa untuk manusia sehingga dia tahu betul akan perbedaan pendapat yang ada. Karena jika tidak demikian, maka dia akan menolak ilmu yang lebih kuat (dalilnya)

19 Abu Abdillah Syamsuddin Muhammad bin Ahmad bin Utsman ad-Dhahabi, Siyaru A 'lami......, h. 45

20 Al-Imam bin Abdil Barr Jami' Bayanil 'Ilmi Wa Ahlihi Juz. 2, h. 46

${ }^{21}$ Al-Amidi Saifud al-Din, Al-Ihkam fi Usul al-Ahkam, Jilid III, (Bairut: Dār a l-Fikr 1996), h. 123 dari pada apa yang selama ini dia yakini", ${ }^{22}$

\section{Penutup}

Berdasarkan uraian di atas menunjukkan bahwa, pentingnya mengetahui perbedaan yang terjadi di kalangan ulama serta dalil dan argumentasinya. Oleh sebab itu tidak tahu seseorang tentang adanya perbedaan pendapat seringkali menimbulkan sikap fanatik buta terhadap pendapatnya sendiri dan menolak setiap pendapat yang berbeda dengan pendapatnya. Padahal kemungkinan pendapat tersebut adalah benar dan didukung oleh dalil yang kuat.

\section{Daftar pustaka}

Al-Amidi Saifud al-Din, Al-Ihkam fi Usul alAhkam, Jilid III, Bairut: Dār a 1-Fikr 1996.

Abu Abdillah Syamsuddin Muhammad bin Ahmad bin Utsman ad Dhahabi, Siyaru A'lami an-Nubala, Juz 10.

Al-Imam bin Abdil Barr Jami' Bayanil 'Ilmi Wa Ahlihi Juz. 2.

Ahmad Muhammad Ali al Faiyumi al-Muqri, Misbahul al-Munir, Bayrut: Maktabah alAsriyah 1997.

Ahmad bin Abdul al-Rahim Al-Faruqi alDahlawi, Al-Inshaf fi Bayani Asbabil ikhtilaffi Ahkam al-Fiqhiyah, tp, t.t.

Ali Muhammad Al-Jurjani, At-Ta'rifat, Dar al Aqsa' t.t.

Taha Jabir Fayyadl Al-Ulwani, Adabul Ikhtilaf fi al- Islam, terj. Abu Fahmi, Jakarta: 1991.

Luis Ma'luf, al-Munjid, hlm. 193. Depdikbud,

Kamus Besar Bahasa Indonesia, Cet.

Ketiga, Jakarta: PN Balai Pustaka, 2005.

Ibn Kashir, Al-Bidayah wal al-Nihayah, Jil.5, Cairo Dār: al-Fajar, 1998 hlm.188.
${ }^{22}$ Al-Imam Abdil Barr 'Jami" Bayanil
'Ilmi..., h. 102 
Imam Bukhari, Sahih al-Bukhari, Jilid 1, Bairut: Dar al Kutub al 'ilmiah, tth.

Imam Ibnu Katsir, Tafsir Al-Qur'an $A l$ 'Azhim, Juz 4, Cet. 2, Cairo: Dar AlTayyibah lin Nasyr wat Tauzi', 1999M/1240H.

Dedi Supriadi, Perbandingan Madzab dengan

Pendekatan Baru, Bandung: Pustaka Setia, 2008.

Muhammad Abu al-Fath al-Bayanuni, Dirasat fi Ikhtilafat al-Fiqhyah, terj. Ali Mustafa Ya'kub, Jakarta: Pustaka Firdaus 1997

Mahmud Syaltut dan M. Ali al-Sayis, Perbandingan Mazhab, Bulan Bintang, Jakarta, 1996.

Muhyiddin Yahya bin Syaraf al-Nawawi, Syarh Sahih Muslim, Juz. 1

Taqiyuddin Ahmad bin Abdus Salam bin Abdullah bin Taimiyah al Harrani, Majmu ah al-Fatawa, Juz ke 20 Bairut:

Dar al-Arabiyah, 1398 H. 